\title{
Maternal microbiome during pregnancy and their impact on the canine microbiome
} in neonates - a review

\author{
Maja Zakošek Pipan* and Janko Mrkun
}

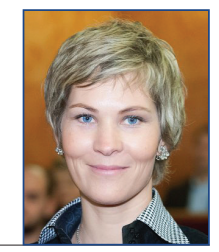

\begin{abstract}
The long-standing hypothesis that the neonatal microbiome is acquired during and after birth has been challenged by recent studies in humans using advanced molecular technologies, which identified bacteria and bacterial DNA and RNA in amniotic fluid, placenta, and meconium. Similar studies have recently been conducted on canine neonates, giving a description of the gut microbiota of newborn puppies and a comparison of different types of parturition on their development. In this review, we summarize
\end{abstract}

the current knowledge of microbiome and microbial alterations in the canine gut, vagina and oral cavity throughout pregnancy, and their effects on the microbiome of the placenta and the meconium in neonatal puppies. We further compare the microbiome knowledge gained in the last decade on human neonates and draw parallels with canine pregnancy and the neonatal microbiome.

Key words: neonatology; birth; puppies; microbiota

\section{Introduction}

Pregnancy is a remarkable biological process involving several healthy developmental changes in many physiological systems to support foetal growth. While most of these changes (e.g. weight gain, hormonal changes, immune system modulations) have been known for decades (Dunlop et al., 2015), the dramatic changes in microbiome composition have only recently been studied and their role is still not yet fully elucidated (Nuriel-Ohayon et al., 2016).

The canine microbiome is composed of the collective microbial communities living in and on the canine body. The gut microbiome is the largest and the most diverse, and plays a very important role in host metabolism, both directly and indirectly affecting most physiological functions (Pilla and Suchodolski, 2020). The hypothesis known as the sterile womb paradigm stated that the foetus develops in a sterile environment and initial bacterial

Maja ZAKOŠEK PIPAN*, DVM, PhD, Assistant, (Corresponding author: e-mail: maja.zakosekpipan@ vf.uni-lj.si), Janko MRKUN, DVM, PhD, Assoc. Professor, Veterinary faculty, University of Ljubljana, Ljubljana, Slovenia 
colonization of the newborn occurs while traveling through the maternal birth canal, and this remained dogma for more than a century (Funkhouser et al., 2013). However, many recent studies in humans and animals, employing modern sequencing technologies, suggest that the placenta has its own microbiota which is also responsible for foetal colonization (Aagaard et al., 2014; Jiménez et al., 2008; Collado et al., 2016; Steel et al., 2005; Bearfield et al., 2002; Zakošek Pipan et al., 2020). Bacterial communities have also been found in the uterus, amniotic fluid and meconium from healthy pregnancies (Bearfield et al., 2002; Jiménez et al., 2005; Steel et al., 2005; Jiménez et al., 2008; Rautava et al., 2012; Aagaard et al., 2014; Hansen et al., 2015; Collado et al., 2016; Parnell et al., 2017; Zhu et al., 2018; Stinson et al., 2019; Zakošek Pipan et al., 2020). It is believed now that gut microbiome acquisition begins in utero and continues to change after parturition (Singh and Mittal, 2019). Several studies in humans also found distinct effects of delivery mode on the gut microbiota composition of newborn babies (Dominguez-Bello et al., 2010; Bäckhed et al., 2015, MacIntyre et al., 2015, Rutayisire et al., 2016). Recently, we showed that mode of delivery also affects the diversity and type of bacterial communities present in the gut of a puppy neonate (Zakošek Pipan et al., 2020).

The purpose of this review is to provide an overview of the initial exposure of the foetus to microbiota - from the placenta, through birth and in the first days of the puppy's life. We describe the potential sources of bacteria and routes by which they access the placenta and infant gut and their influence on puppy health in the first days of life. We suggest that the puppy neonatal microbiome plays an important role in development and that mode of delivery can influence their health in the first weeks of life.

\section{Dam microbiota and}

\section{pregnancy}

\section{Gut microbiota}

It is well known that during gestation, the female body goes through physiological changes in order to support foetal growth and development (van der Weyden et al., 1989; Almeida et al., 2018). Changes in metabolism, hormones, the cardiovascular system and immune modulations are observed. Pregnancy is also considered a pro-inflammatory state that requires physiological adaptation of the mother's immune system. Some degree of immune suppression is essential to accept the growing foetus. On the other hand, strict immunity must remain intact to protect the dam and developing foetuses from infection (Holst et al., 2019). Inflammatory changes during canine pregnancy, manifested as increases in concentrations of CRP and fibrinogen, increases in neutrophils and monocytes, and the activation of granulocytes, monocytes and lymphocytes, should be taken into account. Coinciding with immune alterations, there are noticeable changes in the dam gut microbiota during pregnancy (Vilson et al., 2018). While Fusobacterium, Bacteroidetes and Firmicutes co-dominate in the faecal microbiome of healthy dogs (Pilla and Suchodolski, 2020), Firmicutes, Proteobacteria and Lactobacillus phyla are predominant towards the end of pregnancy. Similar observations were found in humans, where the gut microbiota changes dramatically from the first to the third trimester, with a domination of Actinobacteria and Proteobacteria phyla, and a reduction in species richness (Koren et al., 2012). In order to understand the changes in the gut microbiota, faecal transplantation was used to transfer samples of first- and third-trimester faecal microbiotas to germ-free (GF) mice. GF mice with third-trimester faecal microbiotas gained significantly more 
weight and developed insulin resistance compared to mice transplanted with firsttrimester microbiotas (Koren et al., 2012). These findings directly demonstrate that microbes play an important role in metabolism during pregnancy, contributing to a healthy pregnancy and appropriate foetal development. Weight gain and insulin insensitivity in pregnancy are necessary to provide nutrition for the growing foetus (NurielOhayon et al., 2016). Some of the proposed mechanisms by which gut microbiota play a role in host weight gain during pregnancy include enhanced absorption of glucose and fatty acids, induction of catabolic pathways and stimulation of the immune system (Collado et al., 2008; Koren et al., 2012).

To test whether maternal gut bacteria can be provisioned to foetuses in utero, pregnant mice were fed with milk inoculated with genetically-labelled Enterococcus faecium. After sterile C-section, the meconium microbes of term offspring were examined. Remarkably, E. faecium with the genetic label was cultured from the meconium of pups from mothers fed with inoculated milk, but not from the pups of control mice fed non-inoculated milk (Jimenez et al., 2008).

Changes in the relative abundance of different bacteria during lactation and an increase in bacterial diversity from pregnancy to the end of lactation was also observed in the gut of pregnant and lactating dams (Vilson et al., 2018).

\section{Vaginal microbiota}

While it is well established that the cranial vagina harbours a thriving microbial composition, the uterus was previously considered a sterile environment in order to sustain a healthy pregnancy. However, a recent study in dogs confirmed that the endometrium has its own microbiome which is distinctly different from that of the vagina. Moreover, while the vaginal microbiome changes during different stages of the oestrous cycle, the resident microbiome of the endometrium is present throughout all stages of the oestrous cycle (Lyman et al., 2019). The endometrium also has a higher bacterial diversity, while the vagina has a higher species richness and diversity during oestrus. The most common phyla present in the canine endometrium based on 16sDNA fragment technology were Proteobacteria, Firmicutes, Actinobacteria, and Bacteroidetes, together accounting for $92.6 \%$ of the endometrium microbiome. Pseudomonas, Staphylococcus and Campylobacter were the most prevalent genera (Lyman et al., 2019). Before this approach was possible, attempts were made to isolate microbes from the canine endometrium using culture-based techniques (Baba et al., 1983; Olson et al., 1978; Schultheiss et al., 1999; Maksimović et al., 2012). The success rate of isolating bacteria ranged from 3.8\% (Olson et al., 1978) to $62.5 \%$ (Maksimović et al., 2012), proving that most endometrial microbes are not amenable to culture using standard techniques. Most prevalent organisms isolated in these studies were Staphylococcus, Mycoplasma, while Streptococcus was reported in only one study (Oslson and Mather, 1978). Lactobacillus, Staphylocccus, Mycoplasma and Streptococcus are also the most common bacteria present in the dam vaginal mucosa (Lyman et al., 2019; Zakošek Pipan et al., 2020). However, vaginal mucosa changes dramatically during pregnancy, with Neisseria, Haemophilus and Enterococcus more common during late pregnancy (Zakošek Pipan et al., 2020). Similar findings were observed in humans, where significant changes in the vaginal microbiome were found during pregnancy, including a significant decrease in overall diversity, increased stability and enrichment with Lactobacillus species (Aagaard et al., 2012). 
To summarize, both the endometrium and the vagina of the bitch have a rich microbiota. However, the endometrium microbiota is much more diverse and does not change with the stage of the oestrous cycle, while the vaginal microbiota depends on the stage of the oestrous cycle (Lyman et al., 2019) and it also differs from the beginning to the end of pregnancy (Zakošek Pipan et al., 2020). There is no breed or age effect, though significant animal to animal variations were observed (Lyman et al., 2019).

\section{Oral microbiota}

The dog oral cavity harbours high numbers of diverse bacterial species (up to 600 species). It was discovered that the canine oral microbiome differs significantly from that of humans (Dewhirst et al., 2012).

The most common genera are Lactobacillus, Actinomyces, Leucobacter, Pseudoclavibacter, Propionibacterium, and Staphylococcus. Streptococci appear to represent a minor genus in dog. This is not surprising as simple carbohydrates and sugars are not normally a major constituent of the canine diet and canine saliva has a $\mathrm{pH}$ of approximately 8.0, which is not a good environment for members of this aciduric genus (Dewhirst et al., 2012). Neisseria zoodegmatis, Actinomyces canis and Straphylococcus spp were the predominant phyla found in the oral cavity of the pregnant dam (Zakošek Pipan et al., 2020).

The microbiome of naturally occurring primary endodontic infections in dogs was compared to the microbiome of the subgingival plaque of the same teeth. The microbiome of the diseased endodontic system was found to have a comparable abundance of the same microorganisms as healthy subgingival plaque. Bacteroides and Snowella were the most abundant genera in the endodontic samples, while Porphyromonas and Fusobacterium were significantly more abundant in subgingival plaque (Rodrigues et al., 2019). An altered oral microbiome could have an impact on neonatal outcomes, since pregnant women and women with periodontal disease having higher levels of pathogenic bacteria in the mouth had an increased chance of negative neonatal and maternal outcomes. The most common problems are foetal growth restriction, vulvovaginitis and premature birth due to premature rupture of the foetal membrane (Figueiredo et al., 2019). In humans, the oral microbiota also changes during different stages of pregnancy, though the pathways causing these alterations are still unknown. One hypothesis is that these changes are due to hormones, since oestrogens are known to enhance Candida infections (Fujiwara et al., 2017).

However, it was proposed that overall immunity during pregnancy could be the leading factor for an increased oral microbial load (Nuriel-Ohayon et al., 2016). Unfortunately, in dogs, there are no available data for oral microbiome changes during pregnancy.

\section{Placental microbiota}

The placenta is an organ previously considered to be sterile, and therefore it was believed that all microbes were acquired during and after birth (PerezMuñoz et al., 2017). However, more than three decades ago, the presence of bacteria within placental tissue was confirmed, and newer studies employing modern sequencing technologies have shown that the placenta, amniotic fluid and foetus are not sterile (PerezMuñoz et al., 2017; Zakošek Pipan et al., 2020). Therefore, it was suggested that microbial colonization of the neonate gastrointestinal tract begins in utero (Perez-Muñoz et al., 2017).

Transmission of microbes from the mother to offspring is known in animals, including marine sponges, molluscs, insects, chickens, fish, turtles and mice. 
This suggests that this is an ancient and advantageous evolutionary mechanism enabling the first beneficial microbe inoculation prior to birth (Funkhouser and Bordenstein, 2013).

In other mammalian species, newer research has also reported the presence of an endometrial microbiome in healthy female cows (Machado et al., 2012; Santos and Bicalho, 2012; Jeon et al., 2015; Sicsic et al., 2018) and giant pandas (Yang et al., 2017). Microbes have also been found in foal amniotic fluid (Hemberg et al., 2015), newborn calf meconium (Mayer et al., 2012) and pregnant cow uterus (Karstrup et al., 2017). A recent study showed that Staphylococcus aureus introduced into the bloodstream of pregnant sheep crosses the maternal/foetal barrier and enters the foetus (Yu et al., 2019).

In humans, the major phylum found was Proteobacteria and when compared to all other organs, the bacterial community of the placenta was most similar to the oral microbiota, including species such as Neisseria sp. In dogs, the most common phyla isolated from dam placenta were Staphylococcus spp, Streptococcus spp and Neisseria zoodegmatis (Zakošek Pipan et al., 2020). The similar bacteria present in the placental and oral cavity suggests the passage of bacteria from the oral cavity into the placenta via the bloodstream (Romero et al., 2015). However, microbial density in the placenta was found to be very low in both humans and dogs (Romero et al., 2015; Zakošek Pipan et al., 2020). Therefore, careful sampling is of the utmost importance, and precise verification is necessary to prevent misinterpretation of results that could be due to contamination. With samples collected after vaginal delivery, there is a high chance of contamination from the birth canal, as opposed to placenta samples in a sterile manner collected during C-section.

It is still not clear how microorganisms enter the placental foetal compartment.
One hypothesis is that bacteria ascend from the vagina to the placenta, and/ or that they are transported from the intestinal lumen to the placenta via maternal dendritic cells, and/or the dissemination of oral bacteria via the bloodstream. There is strong evidence for vaginally derived microorganisms (Romero et al., 2015; Zheng et al., 2015). A Lactobacillus-dominant microbiota is considered normal in humans, and they are also strongly correlated with gestational age. However, bacterial translocation via dissemination through the bloodstream is known to be enhanced during pregnancy (Aagaard et al., 2014), enabling the transfer of low numbers of microorganisms to enter circulation and seed into the placenta (Pelzer et al., 2017).

The presence of bacteria in the healthy placenta raises the question of whether they are necessary for normal placental development and function, and whether they are important for contributing to healthy foetal development and how. It was suggested that the placental microbiota has a very important role in early innate immune development, where the placenta is considered a source for antigenic determinants. Even though researchers are still not completely sure whether the bacteria found in the placenta are alive, since they are primarily detecting using DNA sequencing methods, the bacteria that are present do not need to be viable to elicit a immune response. Studies on mice support a role for neonatal immune priming and development in the absence of live microbial exposure. Pups born to mothers transiently colonized in pregnancy are better able to avoid inflammatory responses to microbial molecules and penetration of intestinal microbes (Gomez de Aguero et al., 2016).

\section{Mode of delivery}

In humans, mode of delivery has an impact on the composition of the 
gut microbiota of the newborn. The gut microbiota of vaginally born infants is composed of bacteria present in the vagina of the mother and also includes bacteria present in the mother's gut (Mackie et al., 1999; DominguezBello et al., 2010). In contrast, the gut microbiota of human infants born by C-section resembles maternal skin and the oral microbiota (Bäckhed et al., 2015; MacIntyre et al., 2015). Infants born by C-section had both a lower abundance and diversity of the phyla Actinobacteria and Bacteroidetes, and a higher abundance and diversity of the phylum Firmicute. At the colonization level, the genera Bifidobacterium and Bacteroides appear to be significantly more frequent in vaginally delivered infants compared with those delivered by $\mathrm{C}$-section. These infants were more colonized by the Clostridium, and Lactobacillus genera.

Similar observations were also found in dogs, where C-section born puppies had a meconium microbiota composed of the same bacteria present in the oral cavity of their mothers, while vaginally born puppies had mostly bacteria present in the vagina of their mothers. Moreover, total microbial diversity was significantly higher in vaginally delivered compared to C-section delivered puppies (Zakošek Pipan et al., 2020). The high abundance of Bifidobacterium species in infants is considered to be necessary for development and maturation of the immune system to sustain health, suggesting that $\mathrm{C}$-section may lead to immune disorders (Kelly et al., 2004). Contrary, a high abundance of Clostridium difficile in C-section infants could be a reason for severe gastrointestinal infections during infancy (Rutayisire et al., 2016). In humans, it was suggested that bacterial transmission from the vagina to the newborn is disrupted in a C-section birth, which can have long-term health implications, including a higher incidence of asthma (Kero et al., 2002) and celiac disease (Mårild et al., 2012). However, it is still not clear whether these different bacterial communities in neonates born vaginally compared to those delivered by C-section have a long-term effect on their development, metabolism and health.

In puppies, relative weight gains were higher on days 2, 3 and 4 in vaginally born puppies compared to puppies born by $\mathrm{C}$-section, and it was suggested that this is due to the increased meconium microbiota diversity in vaginally delivered puppies and consequently better nutrition uptake from the gut (Zakošek Pipan et al., 2020).

Interesting results were obtained in our previous study when looking at the puppy microbiota and weight gain in the first days of life, where puppies with bacterial microbiome in the meconium or in the placenta gained more weight than puppies born with a sterile meconium or placenta. The weight gain difference became significant on the $3^{\text {rd }}$ and $4^{\text {th }}$ day. Even though the difference was not significant on day 1 , from a clinical point of view, puppies with a sterile placenta lost on average $1.9 \%$ of their body weight, while those with placental microbiota gained on average $0.06 \%$ of their body weight (Zakošek Pipan et al., 2020). This fact is truly important for the better survival of puppies in the first week of life, when mortality is known to be relatively high (Tønnessen et al., 2012).

\section{Gastrointestinal development of the microbiome in neonates}

Gastrointestinal tract colonization in mammals starts even before the newborn exits the birth canal. Initial colonization varies and reflects the mode of delivery and nutrition, and the establishing microbiome increases in diversity over time (Bäckhed et al., 2015). Knowledge about the gastrointestinal development of the intestinal microbiome in dogs and cats is limited. Microbiome studies and the impact of bacteria present in the 
gut has only recently gained interest. In a longitudinal study of the feline faecal microbiome, Deusch et al. (2015) found that the early faecal microbiome was characterized by a high degree of inter-individual variation and that intraindividual diversity and compositional stability increased with age. The same was observed in humans, where different populations were also found to have a different composition of gut microbiome, which could be associated with the higher prevalence of certain diseases in some populations (Levin et al., 2016). Despite individual variability in the healthy human microbiota, an individual's microbiota will remain stable over time, and more than $60 \%$ of strains remained stable over the course of five years (Faith et al., 2013).

Similarly to humans, adult littermates have been found to present a more similar microbiome composition than unrelated dogs (Hand et al., 2013; Vilson et al., 2018), while a strong environmental effect was also found on early gut microbiota (Vilson et al., 2018). This sheds light on genetics and environmental factors and their influence (Hand et al., 2013). In a study comparing dogs and their owners, significant sharing of skin microbiota and even faecal microbiota between dog owners and their pets was observed (Song et al., 2013). While the overall impact of this microbiota sharing is likely small, it should be considered in households with immunocompromised individuals due to the zoonotic impact (Oh et al., 2015).

When the neonatal dog microbiome was studied, the faecal microbiota in puppies was observed to change from 2 to 56 days after birth. Major phylogenetic changes were noted at all taxonomiclevels, with the most profound changes being a shift from primarily Firmicutes in puppies at 2 days of age to a co-dominance of Bacteroidetes, Fusobacteria, and Firmicutes by 21 days of age. These shifts were characterized by increased microbial diversity. It was suggested that increases in species richness may be indicative of the growing strength and resilience of the puppy gastrointestinal tract against environmental pathogens. By day 42, microbial communities appeared to have achieved relative stability (Guard et al., 2017). This is in agreement with studies on human infants, where temporal variability during the development of intestinal microbiota at the phylum level was higher in the infant than in the adult intestinal microbiota (Palmer et al., 2007). Despite this high variability, core bacterial groups such as Proteobacteria, Bacteroides, Firmicutes and Actinobacteria were present in both the infant and adult microbiota. At around 6 months of life, the human intestinal microbiota became dominated by Bacteroides and Firmicutes, which began to shape the generic adult-like profile. In neonatal dogs, the variability of these major bacterial phyla was high, with a range of $29 \pm 95 \%$ of sequences belonging to Firmicutes in 2 -day old puppies, as opposed to $10 \pm 35 \%$ of the sequences in their mothers. By the time the puppies had reached 56 days of age, their faecal microbiota included a higher greater diversity of phylum level bacteria, dominated by Bacteroidetes, Firmicutes, Fusobacteria, and Proteobacteria (Guard et al., 2017). This is similar to humans, where the relative abundance of Lactobacillus and Bifidobacterium decreased with age, while Bacteriodes and bacterial genes associated with the ability to metabolize complex carbon sources increased with age (Burton et al., 2016).

In another study on dogs, a 100-fold increase in Lactobacilli was detected by day 21 in the luminal contents of the distal colon in neonate beagle puppies. This increase can be explained since canine milk is a natural source of lactobacilli for the suckling puppy (Martín et al., 2010). In humans, it was also proven that breast milk is a source of lactic acid bacteria in the infant gut (Martín et al., 2003). 
Guard et al. (2017) observed a significant difference in intestinal microbiota between small and large breed puppies, but only after 42 days of age. Their explanation for the different microbial communities observed were the dietary differences between different size breeds. Other studies designed to assess the impact of the diet have revealed valuable information about the intestinal microbiome in young cats and dogs. The faecal microbiomes of kittens fed high- or moderate-protein diets after weaning were more similar between littermates at 8 weeks of age, while at 12 weeks of age, diet emerged as the primary factor driving interindividual similarities (Vester et al., 2009). Associations have been observed between diet-induced changes in the microbiota of kittens and complex metabolic and hormonal effects in the host (Hooda et al., 2013). In that study, the faecal presence of Lactobacillaceae was negatively correlated with body weight and positively correlated with blood leptin concentrations. The presence of Bifidobacteraceae was positively correlated with blood ghrelin and negatively correlated with blood triglycerides. Kittens fed a highprotein, low-carbohydrate diet had a lower relative abundance of these organisms. It was also found that dogs fed with supplements of bovine colostrum had significantly increased gut microbiota diversity and stability compared to the control group, which in turn had a significant influence on better immune response in dogs (Satyaraj et al., 2013). The association between diet-induced compositional differences in the faecal microbiome and hormones regulating metabolism is suggestive of a high impact of the intestinal microbiome in regulating developmental metabolism (Hooda et al., 2013) and immune response (Satyaraj et al., 2013).

\section{Conclusions}

In this review, we discuss the microbiome composition in neonates. We describe the significant alterations in microbial composition in a variety of body sites (gut, vagina, oral cavity, placenta). Most studies included in the review present changes in microbiota composition, richness and diversity between groups, though the actual effect of microbial changes on host development and overall health remains unknown. We believe that microbial changes have a significant impact on development, and future research into how the microbiome is developed in puppies and the factors influencing its transmission is essential in order to solve this puzzle.

With more and more studies confirming the presence of bacteria in the placenta and endometrium, it is now clear that the placenta has its own microbiota and its composition is likely to have an impact on pregnancy outcomes. However, the mechanisms by which this occurs remains unclear and before conclusions can be drawn about the in utero exchange of bacteria during pregnancy, continued research is required to determine the origin of these bacteria, and whether they are responsible for foetal metabolic and immune development.

Results of studies have also pointed out that the intestinal microbiome is an essential contributor to mammalian health and an active participant in host developmental physiology. Early colonizers have a very important role on the development of mammalian gut microbiota. A combination of parental, environmental, dietary, and pathogen exposure shape the development of gut microbiota and provide a basis for a unique mammalian microbiota. However, there is a paucity of longitudinal studies of the developing microbiome in small animals, and fundamental questions regarding its maturation and impact on 
host physiology remain unanswered. Therefore, additional longitudinal studies are needed to determine the origin and functional impact of the neonatal microbiome in dogs, and to describe the process of microbiome maturation during host development and its impact on early-life and adult health outcomes.

A better understanding of the neonatal microbiota, identifying the beneficial and detrimental microbial components, and their role during pregnancy, parturition and early development may contribute to the identification of new therapeutic targets to improve pregnancy outcomes and neonatal survival.

\section{References}

1. AAGAARD, K., J. MA, K. M. ANTONY, R. GANU, J. PETROSINO and J. VERSALOVIC (2014): The placenta harbors a unique microbiome. Sci. Transl. Med. 6, 237ra65.

2. AlMEIDA, V. T., R. A. R. USCATEGUI, A. A. CAMACHO, M. G. SOUSA, V. SANTOS, M. C. MARONEZI et al. (2018): Influence of estrous cyclend and gestation on cardiovascular system of bitches. Anim. Reprod. Sci. 192, 35-43.

3. BABA, E., H. HATA, T. FUKATA and A. ARAKAWA (1983): Vaginal and uterine microflora of adult dogs. A. J. Vet. Res. 44, 606-609.

4. BÄCKHED, F., J. ROSWALL, Y. PENG, Q. FENG, H. JIA, P. KOVATCHEVA-DATCHARY, Y. LI, Y. XIA, H. XIE, H. ZHONG, et al. (2015): Dynamics and Stabilization of the Human Gut Microbiome during the First Year of Life. Cell Host Microbe. 17, 690-703.

5. BEARFIELD, C., E. S. DAVENPORT, V. SIVAPATHASUNDARAM and R. P. ALLAKER (2002): Possible association between amniotic fluid micro-organism infection and microflora in the mouth. BJOG. 109, 527-533.

6. BURTON, E. N., E. O'CONNOR, A. C. ERICSSON and C. L. FRANKLIN (2016): Evaluation of fecal microbiota transfer as treatment for postweaning diarrhea in research-colony puppies. J. Am. Assoc. Lab. Anim. Sci. 55, 582-587.

7. COLLADO, M. C., E. ISOLAURI, K. LAITINEN and S. SALMINEN (2008): Distinct composition of gut microbiota during pregnancy in overweight and normal-weight women. Am. J. Clin. Nutr. 88, 894-899.

8. COLlADO, M. C., S. RAUTAVA, J. AAKKO, E. ISOLAURI a S. SALMINEN (2016): Human gut colonisation may be initiated in utero by distinct microbial communities in the placenta and amniotic fluid. Sci. Rep. 6, 23129.
9. DEUSCH, O., C. O'FLYNN, A. COLYER, K. S. SWANSON, D. ALLAWAY and P. MORRIS (2015): A longitudinal study of the feline faecal microbiome identifies changes into early adulthood irrespective of sexual development. Plos One 10, e0144881.

10. DEWHIRST, F. E., E. A. KLEIN, E. C. THOMPSON, J. M. BLANTON, T. CHEN, L. MILELLA, C. M. BUCKLEY, I. J. DAVIS, M. L. BENNETT and Z. V. MARSHALL-JONES (2012): The canine oral microbiome. Plos One 7, e36067.

11. DOMINGUEZ-BELLO, M. G., E. K. COSTELLO, M. CONTRERAS, M. MAGRIS, G. HIDALGO, N. FIERER and R. KNIGHT (2010): Delivery mode shapes the acquisition and structure of the initial microbiota across multiple body habitats in newborns. Proc. Natl. Acad. Sci. USA. 107, 1197111975.

12. DUNLOP, A. L., J. G. MULLE, E. P. FERRANTI, S. EDWARDS, A. B. DUNN, and E. J. CORWIN (2015): Maternal Microbiome and Pregnancy Outcomes That Impact Infant Health: A Review. Adv. Neonatal Care. 15, 377-385.

13. FAITH, J. J., J. L. GURUGE, M. CHARBONNEAU, S. SUBRAMANIAN, H. SEEDORF, A. L. GOODMAN, J. C. CLEMENTE, R. KNIGHT, A. C. HEATH, R. L. LEIBEL, M. ROSENBAUM and J. I. GORDON (2013): The long-term stability of the human gut microbiota. Science 341(6141), 1237439.

14. FIGUEIREDO, M. S. Y. TAKITA, B. DOURADO, H. S. MENDES, E. O. TERAKADO, H. NUNES and C. FONSECA (2019): Periodontal disease: Repercussions in pregnant woman and newborn health-A cohort study. PLoS One 14, e0225036.

15. FUJIWARA, N., K. TSURUDA, Y. IWAMOTO, F. KATO, T. ODAKI, N. YAMANE, Y. HORI, Y. HARASHIMA, A. SAKODA, A. TAGAYA, H KOMATSUZAWA, M. SUGAI and M. NOGUCHI (2017): Significant increase of oral bacteria in the early pregnancy period in Japanese women. J. Investig. Clin. Dent. 8, 10.

16. FUNKHOUSER, L. J. and S. R. BORDENSTEIN (2013): Mom knows best: the universality of maternal microbial transmission. PLoS Biol. 11, e1001631-e1001631.

17. GOMEZ DE AGÜERO, M., S. C. GANALVONARBURG, T. FUHRER, S. RUPP, Y. UCHIMURA, H. LI, A. STEINERT, M. HEIKENWALDER, S. HAPFELMEIER, U. SAUER, K. D. MCCOY and A. J. MACPHERSON (2016): The maternal microbiota drives early postnatal innate immune development. Science 351 (1296), e1302.

18. GUARD, B. C., H. MILA, J. M. STEINER, C. MARIANI, J. S. SUCHODOLSKI and S. CHASTANT-MAILLARD (2017): Characterization of the fecal microbiome during neonatal and early pediatric development in puppies. PLoS One 12, e0175718.

19. HANSEN, R., K. P. SCOTT, S. KHAN, J. C. MARTIN, S. H. BERRY, M. STEVENSON, A. OKPAPI, M. J. MUNRO, and G. L. HOLD (2015): First-Pass Meconium Samples from Healthy Term 
Vaginally-Delivered Neonates: An Analysis of the Microbiota. PLoS One 10, e0133320-e0133320.

20. HAND, D., C. WALLIS, A. COLYER and C. W. PENN (2013): Pyrosequencing the canine faecal microbiota: breadth and depth of biodiversity. PLoS One 8, e53115.

21. HEMBERG, E., S. EINARSSON, G. KÚTVÖLGYI, N. LUNDEHEIM, E. BAGGE, V. BÅVERUD, B. JONES and J. M. MORRELL (2015): Occurrence of bacteria and polymorphonuclear leukocytes in fetal compartments at parturition; relationships with foal and mare health in the peripartum period. Theriogenology 84, 163-169.

22. HOODA, S., B. M. VESTER BOLER, K. R. KERR, S. E. DOWD and K. S. SWANSON (2013): The gut microbiome of kittens is affected by dietary protein: carbohydrate ratio and associated with blood metabolite and hormone concentrations. Br. J. Nutr. 109, 1637-1646.

23. HOLST, B. S., M. H. GUSTAVSSON, A. JOHANNISSON, A. HILLSTRÖM, E. STRAGE, U. OLSSON, E. AXNÉR and I. LILLIEHÖÖK (2019): Inflammatory changes during canine pregnancy. Theriogenology 125, 285-292.

24. JEON, S. J., A. VIEIRA-NETO, M. GOBIKRUSHANTH, R. DAETZ, R. D. MINGOTI, A. C. PARIZE, S. L. DE FREITAS, A. N. DA COSTA, R. C. BICALHO, S. LIMA, K. C. JEONG and K. N. GALVÃO (2015): Uterine microbiota progression from calving until establishment of metritis in dairy cows. Appl. Environ. Microbiol. 81, 6324-6332.

25. JIMÉNEZ, E., L. FERNÁNDEZ, M. L. MARÍN, R. MARTÍN, J. M. ODRIOZOLA, C. NUENOPALOP, A. NARBAD, M. OLIVARES, J. XAUS and J. M. RODRÍGUEZ (2005): Isolation of Commensal Bacteria from Umbilical Cord Blood of Healthy Neonates Born by Cesarean Section. Curr. Microbiol. 51, 270-274.

26. JIMÉNEZ, E., M. L. MARÍN, R. MARTÍN, J. M. ODRIOZOLA, M. OLIVARES, J. XAUS, L. FERNÁNDEZ and J. M. RODRÍGUEZ (2008): Is meconium from healthy newborns actually sterile? Res. Microbiol. 159, 187-193.

27. KARSTRUP, C. C., K. KLITGAARD, T. K. JENSEN, J. S. AGERHOLM and H. G. PEDERSEN (2017): Presence of bacteria in the endometrium and placentomes of pregnant cows. Theriogenology 99, $41-47$.

28. KERO, J., M. GISSLER, M. M. GRÖNLUND, P. KERO, P. KOSKINEN, E. HEMMINKI and E. ISOLAURI (2002): Mode of delivery and asthma -is there a connection? Pediatr. Res. 52, 6-11.

29. KELLY, D., J. I. CAMPBELL, T. P. KING, G. GRANT, E. A. JANSSON, A. G. COUTTS, S. PETTERSSON and S. CONWAY (2004): Commensal anaerobic gut bacteria attenuate inflammation by regulating nuclear-cytoplasmic shuttling of PPAR-gamma and RelA. Nat. Immunol. 5, 104-112.

30. KOREN, O., J. K. GOODRICH, T. C. CULLENDER, A. SPOR, K. LAITINEN, H. K. BÄCKHED, A. GONZALEZ, J. J. WERNER, L. T. ANGENENT,
R. KNIGHT et al. (2012): Host remodeling of the gut microbiome and metabolic changes during pregnancy. Cell 150, 470-480.

31. LEVIN, A. M., A. R. SITARIK, S. L. HAVSTAD, K. E. FUJIMURA, G. WEGIENKA, A. E. CASSIDYBUSHROW, H. KIM, E. M. ZORATTI, N. W. LUKACS, H. A. BOUSHEY, D. R. OWNBY, S. V. LYNCH and C. C. JOHNSON (2016): Joint effects of pregnancy, sociocultural, and environmental factors on early life gut microbiome structure and diversity. Sci. Rep. 6, 31775.

32. LYMAN, C. C., G. R. HOLYOAK, K. MEINKOTH, X. WIENEKE, K. A.CHILLEMI, and U. DESILVA (2019): Canine endometrial and vaginal microbiomes reveal distinct and complex ecosystems. PLoS One 14, e0210157.

33. MACHADO, V. S., G. OIKONOMOU, M. L. BICALHO, W. A. KNAUER, R., GILBERT, R. C. BICALHO (2012): Investigation of postpartum dairy cows' uterine microbial diversity using metagenomic pyrosequencing of the 16S rRNA gene. Vet. Microbiol. 159, 460-469.

34. MACINTYRE, D. A., M. CHANDIRAMANI, Y. S. LEE, L. KINDINGER, A. SMITH, N. ANGELOPOULOS, B. LEHNE, S. ARULKUMARAN, R. BROWN, T. G. TEOH, E. HOLMES, J. K. NICOHOLSON, J. R. MARCHESI and P. R. BENNETT (2015): The vaginal microbiome during pregnancy and the postpartum period in a European population. Sci. Rep. 5, 8988.

35. MACKIE, R. I., A. SGHIR and H. R. GASKINS (1999): Developmental microbial ecology of the neonatal gastrointestinal tract. Am. J. Clin. Nutr. 69,1035S-1045S.

36. MAKSIMOVIĆ, A., Z. MAKSIMOVIĆ, S. FILIPOVIĆ, H. BEŠIROVIĆ and M. RIFATBEGOVIĆ (2012): Vaginal and uterine bacteria of healthy bitches during different stages of their reproductive cycle. Vet. Rec. 171, 375.

37. MÅRILD, K., O. STEPHANSSON, S. MONTGOMERY, J. A. MURRAY, J. F. LUDVIGSSON (2012): Pregnancy outcome and risk of celiac disease in offspring: a nationwide casecontrol study. Gastroenterology 142, 39-45.e3.

38. MARTÍN, R., S. LANGA, C. REVIRIEGO, E. JIMÍNEZ, M. L. MARÍN, J. XAUS, L. FERNÁNDEZ and J. M. RODRÍGUEZ (2003): Human milk is a source of lactic acid bacteria for the infant gut. J. Pediatr. 143, 754-758.

39. MARTÍN, R., M. OLIVARES, M. PÉREZ, M., J. XAUS, C. TORRE, L. FERNÁNDEZ and J. M. RODRÍGUEZ (2010): Identification and evaluation of the probiotic potential of lactobacilli isolated from canine milk. Vet. J. 185, 193-198.

40. MAYER, M., A. ABENTHUM, J. M. MATTHES, D. KLEEBERGER, M. J. EGE, C. HÖLZEL, J. BAUER and K. SCHWAIGER (2012): Development and genetic influence of the rectal bacterial flora of newborn calves. Vet. Microbiol. 161, 179-185.

41. NURIEL-OHAYON, M., H. NEUMAN and O. KOREN (2016): Microbial Changes during 
Pregnancy, Birth, and Infancy. Front. Microbiol. 7, 1031.

42. OH, C., K. LEE, Y. CHEONG, S. W. LEE, S. Y. PARK, C. S. SONG, I. S. CHOI and J. B. LEE (2015): Comparison of the Oral Microbiomes of Canines and Their Owners Using Next-Generation Sequencing. PLoS One 10, e0131468.

43. OLSON, P. N. and E. C. MATHER (1978): Canine vaginal and uterine bacterial-flora. J. Am. Vet. Med. Assoc. 172, 708-711.

44. PALMER, C., E. M. BIK, D. B. DIGIULIO, D. A RELMAN and P. O. BROWN (2007): Development of the human infant intestinal microbiota. PLoS Biol. 5, e177.

45. PARNELL, L. A., C. M. BRIGGS, B. CAO, O. DELANNOY-BRUNO, A. E. SCHRIEFFER and I. U. MYSOREKAR (2017): Microbial communities in placentas from term normal pregnancy exhibit spatially variable profiles. Sci. Rep. 7, 11200.

46. PELZER, E., L. F. GOMEZ-ARANGO, H. L. BARRETT AND M. D. NITERT (2017): Review: Maternal health and the placental microbiome. Placenta 54, 30-37.

47. PEREZ-MUÑOZ, M. E., M. C. ARRIETA, A. E. RAMER-TAIT and J. WALTER (2017): A critical assessment of the "sterile womb" and "in utero colonization" hypotheses: implications for research on the pioneer infant microbiome. Microbiome 5, 48

48. PILLA, R. and J. S. SUCHODOLSKI (2020): The Role of the Canine Gut Microbiome and Metabolome in Health and Gastrointestinal Disease. Front. Vet. Sci. 6, 498 .

49. RAUTAVA, S, M. C. COLLADO, S. SALMINEN, E. ISOLAURI (2012): Probiotics Modulate HostMicrobe Interaction in the Placenta and Fetal Gut: A Randomized, Double-Blind, Placebo-Controlled Trial. Neonatology 102, 178-184.

50. RODRIGUES, M. X., A. NEMEC, N. FIANI, R. C. BICALHO and S. PERALTA (2019): Endodontic Microbiome of Fractured Non-vital Teeth in Dogs Determined by $16 \mathrm{~S}$ rRNA Gene Sequencing. Front. Vet. Sci. $6,348$.

51. ROMERO, R., J. MIRANDA, T. CHAIWORAPONGSA, P. CHAEMSAITHONG, F. GOTSCH, Z. DONG, A. I. AHMED, B. H. YOON, S. S. HASSAN, C. J. KIM, S. J. KORZENIEWSKI, L. YEO and Y. M. KIM (2015): Sterile intra-amniotic inflammation in asymptomatic patients with a sonographic short cervix: prevalence and clinical significance. J. Matern. Fetal Neonatal Med. 28, 1343-1359.

52. RUTAYISIRE, E., K. HUANG, Y. LIU and F. TAO (2016): The mode of delivery affects the diversity and colonization pattern of the gut microbiota during the first year of infants' life: a systematic review. BMC Gastroenterol. 16, 86.

53. SANTOS, T. M. and R. C. BICALHO (2012): Diversity and succession of bacterial communities in the uterine fluid of postpartum metritic, endometritic and healthy dairy cows. PLoS One 7, e53048.
54. SATYARAJ, E., A. REYNOLDS, R. PELKER, J. LABUDA, P. ZHANG and P. SUN (2013): Supplementation of diets with bovine colostrum influences immune function in dogs. Br. J. Nutr. 110, 2216-2221.

55. SCHULTHEISS, P. C., R. L. JONES, M. L., KESEL and P. N. OLSON (1999): Normal bacterial flora in canine and feline uteri. J. Vet. Diag. Invest. 11, 560-562.

56. SICSIC, R., T. GOSHEN, R. DUTTA, N. KEDEMVAANUNU, V. KAPLAN-SHABTAI, Z. PASTERNAK, Y. GOTTLIEB, N. Y. SHPIGEL and T. RAZ (2018): Microbial communities and inflammatory response in the endometrium differ between normal and metritic dairy cows at 5-10 days post-partum. Vet. Res. 49, 77.

57. SINGH, A. and M. MITTAL (2019). Neonatal microbiome - a brief review. J. Matern. Fetal. Neonatal Med. 1-8.

58. SONG, S. J., C. LAUBER, E. K. COSTELLO, C. A. LOZUPONE, G. HUMPHREY, D. BERG-LYONS, J. G. CAPORASO, D. KNIGHTS, J. C. CLEMENTE, S. NAKIELNY, J. I. GORDON, N. FIERER and R. KNIGHT (2013): Cohabiting family members share microbiota with one another and with their dogs. Elife 2, e00458.

59. STEEL, J. H., S. MALATOS, N. KENNEA, A. D. EDWARDS, L. MILES, P. DUGGAN, P. R. REYNOLDS, R. G. FELDMAN and M. H. SULLIVAN (2005): Bacteria and Inflammatory Cells in Fetal Membranes Do Not Always Cause Preterm Labor. Pediatr. Res. 57, 404-411.

60. STINSON, L. F., M. C. BOYCE, M. S. PAYNE and J. A. KEELAN (2019): The Not-so-Sterile Womb: Evidence That the Human Fetus Is Exposed to Bacteria Prior to Birth. Front. Microbiol. 10, 1124.

61. TØNNESSEN, R., K.S. BORGE, A. NØDTVEDT and A. INDREBØ (2012): Canine perinatal mortality: a cohort study of 224 breeds. Theriogenology 77, 1788-1801.

62. VAN DER WEYDEN, G. C., M. A. TAVERNE, S. J. DIELEMAN, Y. WURTH, M. M. BEVERS and H. A. VAN OORD (1989): Physiological aspects of pregnancy and parturition in dogs. J. Reprod. Fertil. Suppl. 39, 211-224.

63. VESTER, B. M. D. B. L., I. S. MIDDELBOS, C. J. APANAVICIUS, M. BRITTANY, D. C. LUBBS and K. S. SWANSON (2009): Faecal microbial populations of growing kittens fed high- or moderate-protein diets. Arch. Animal. Nutrit. 63, 254-265.

64. VILSON, A., Z. RAMADAN, Q. LI, ^. HEDHAMMAR, A. REYNOLDS, J. SPEARS, J. LABUDA, R. PELKER, B. BJÖRKSTÉN, J. DICKSVED, H. HANSSON-HAMLIN (2018): Disentangling factors that shape the gut microbiota in German Shepherd dogs. PLoS One 13, e0193507.

65. YU, K., M. D. RODRIGUEZ, Z. PAUL, E. GORDON, K. RICE, E. W. TRIPLETT, M. KELLER-WOOD and C. E. WOOD (2019): Proof of principle: Physiological transfer of small numbers of bacteria from mother 
to fetus in late-gestation pregnant sheep. PLoS One 14, e0217211.

66. YANG, X., G. CHENG, C. LI, J. YANG, J. LI, D. CHEN, W. ZOU, S. JIN, H. ZHANG, D. LI, Y. HE, C. WANG, M. WANG and H. WANG (2017): The normal vaginal and uterine bacterial microbiome in giant pandas (Ailuropoda melanoleuca). Microbiol. Res. 199, 1-9.

67. ZAKOŠEK PIPAN, M., L. KAJDIČ, A. KALIN, T. PLAVEC and I. ZDOVC (2020): Do newborn puppies have their own microbiota at birth?
Influence of type of birth on newborn puppy microbiota. Theriogenology 152, 18-28.

68. ZHENG, J., X. XIAO, Q. ZHANG, L. MAO, M. YU and J. XU (2015): The Placental Microbiome Varies in Association with Low Birth Weight in Full-Term Neonates. Nutrients 7, 6924-6937.

69. ZHU, L., F. LUO, W. HU, Y. HAN, Y. WANG, H. ZHENG, X. GUO and J. QIN (2018): Bacterial Communities in the Womb During Healthy Pregnancy. Front. Microbiol. 9, 2163-2163.

\section{Majčinski mikrobiom tijekom gravidnosti i njegov utjecaj na pseći mikrobiom u novorođenčadi - pregledni članak}

Dr. sc. Maja ZAKOŠEK PIPAN, dr. med. vet., asistentica, dr. sc. Janko MRKUN, dr. med. vet., izvanredni profesor, Veterinarski fakultet Univerzitet u Ljubljani, Ljubljana, Slovenija

Dugotrajnu hipotezu da se neonatalni mikrobiom stječe tijekom i nakon rođenja izazvale su nove studije na ljudima u kojima su identificirane bakterije, bakterijski DNK i RNK u plodnoj vodi, placenti i mekoniju naprednim molekularnim tehnologijama. Nedavno je otkriveno i $u$ novorođenih pasa gdje su prve studije opisale crijevnu mikrobiotu novorođenih psića i usporedbu različitih vrsta porođaja na njegov razvoj. U ovom preglednom članku, dat sažetak trenutnih spoznaja o mikrobiomu i promjenama mikroorganizama u crijevima, vagini i usnoj šupljini tijekom gravidnosti kuja koje utječu na mikrobiom placente i mekonija novorođenih psića. Nadalje, uspoređujemo saznanja o mikrobiomu stečena tijekom posljednjih deset godina $u$ novorođenčadi ljudi povučene su paralele s gravidnsti u pasa i neonatalnim mikrobiomom.

Ključne riječi: neonatologija, porođaj, štenci, mikrobiota 